\title{
A DIGITAL PRE-INVENTORY OF ARCHITECTURAL HERITAGE IN KOSOVO USING DOCU-TOOLS®
}

\author{
C. Jäger-Klein ${ }^{\text {a }}$, A. Kryeziu ${ }^{\text {b }}$, V. Ymeri Hoxha ${ }^{c}$, M. Rant $^{\mathrm{d}}$
}

\author{
${ }^{a}$ TU-Wien, Institute of History of Art, Building Archaeology and Restoration, Vienna, Austria, \\ jaeger-klein@tuwien.ac.at \\ ${ }^{\mathrm{b}}$ UBT, Faculty of Architecture, Prishtina, Kosovo, arnisa.kryeziu@ubt-uni.net \\ c PhD CandidateTU-Wien, , Vienna, Austria, verona.ymeri@gmail.com \\ d Sustain Solutions GmbH, Vienna, Austria, M.Rant@docu-tools.com
}

Commission VI, WG VI/4

KEY WORDS: Cultural Heritage, Kosovo, Architecture, Documentation, Digital Inventory, Docu-tools®, Transition Countries, Open
Society

\begin{abstract}
:
Kosovo is one of the new states in transition in the Western Balkans and its state institutions are not yet fully functional. Although the territory has a rich architectural heritage, the documentation and inventory of this cultural legacy by the national monument protection institutions is insufficiently-structured and incomplete. Civil society has collected far more material than the state, but people are largely untrained in the terminology and categories of professional cultural inventories and in database systems and their international standards. What is missing is an efficient, user-friendly, low-threshold tool to gather together and integrate the various materials, archive them appropriately and make all the information suitably accessible to the public. Multiple groups of information-holders should be able to feed this open-access platform in an easy and self-explanatory way. In this case, existing systems such as the Arches Heritage Inventory and Management System would seem to be too complex, as it pre-supposes a certain understanding of the standard terminology and internationally used categories. Also, the platform as archive must be able to guarantee the integrity and authenticity of the inputted material to avoid abuse through unauthorized users with nationalistic views. Such an open-access lay-inventory would enable Kosovo to meet the urgent need for a national heritage inventory, which the state institutions have thus far been able to establish. The situation is time-sensitive, as Kosovo will soon repeat its attempt to join UNESCO, having failed to do so in 2015, receiving only a minimum number of votes in favour.

In Austria, a program called docu-tools ${ }^{\circledR}$ was recently developed to tackle a similar problem. It can be used by non-professionals to document complicated and multi-structured cases within the building process. Its cloud and app-design structure allows archiving enormous numbers of images and documents in whatever format. Additionally, it allows parallel access by authorized users and avoids any hierarchy of structure or prerequisites for its users. The archived documents cannot be changed after input, which gave this documentation tool acclaimed court relevance. The following article is an attempt to explore the potential for this tool to prepare Kosovo for a comprehensive heritage inventory.
\end{abstract}

\section{INTRODUCTION}

Austria is one of the birthplaces of standard heritage inventories with its Topography of Art series (Österreichische KunstTopographie), initiated in 1889 (1907) in the times of the AustroHungarian Monarchy by the k.k. Central-Commision on monuments. To date, Austria has published more than 60 volumes (of the (approximately) 80 possible maximum), but some administrative districts have not yet been covered by the series. For political reasons, the German Dehio handbook system was introduced in the second decade of the $20^{\text {th }}$ century, in 1933, and implemented in parallel to the existing art topographies approach. Although the smaller, less comprehensive but more practical handbook format series succeeded in terms of completion, the topography series are still the most comprehensive cultural heritage information on Austria. However, it took more than a hundred years of continuous support of state-based institutions to document most of the country's cultural heritage. The Austrian administrative districts (Verwaltungsbezirke und Stautarstädte) set up the structure of the Topographies of Art. Originally, there was one Dehio handbook for each of the nine provinces of Austria, and these were collected in one volume and completed already more than thirty years ago. However, in the recent re-issue, each province occupies a kind of quarter-volume, to keep them in a handy book format.

Both versions of the official, open-access inventory - the Dehio handbook format and the art topographies series - are available in printed book format, i.e., not in a digital version, like the institutional, non-public inventory of the federal state, which is used by the institution itself for listing and monitoring. The Federal Institute of Monument Protection is now in charge of both versions. Originally, the Federal Institute of Monument protection made the Dehio handbook accessible to the public. The Art History Department of the University of Vienna (Kunsthistorisches Institut) launched the art topography series. Although the research efforts of the Federal Institute of Monument Protection are undoubtedly vast, precise and dependable, it is a far from quick inventory method. Currently, there are serious problems in digitalizing the collected information, including archive material, historic photographs and 
plan graphics, from nearly 150 years into a single digital database. Only old cultural nations can afford to go ahead with inventories of that kind. Other regions of the world, like the transitionary countries in the Western Balkans will have to use more contemporary and efficient inventory tools, which will allow ongoing refinements and enlargements after a first round of documentation. Thanks to the digital revolution, such tools are now available. Existing systems such as The Arches Heritage Inventory and Management System, developed by the Getty Conservation Institute and World Monuments Fund, which is an open-source, web-based, geospatially-enabled information system to help inventory and manage immoveable cultural heritage, are far too complex to be used to inventory 'from scratch' in a region where the war has led to large gaps in education. Before structuring the collected material according to International Core Data Standards for Archaeological and Architectural Heritage (CDS) into the CIDOC Conceptual Reference Model (CRM) as a semantic framework, the material has to be collected with completely intuitive, user-friendly tools.

Such a tool was recently developedy by an Austrian company. The tool, called docu-tools ${ }^{\circledR}$, was originally designed as an application for the efficient documentation of buildings on-site, during and immediately after their hot construction phase. For documenting damages within the new terminal of Vienna airport, an expert witness would have had to describe the thousands of weakness in the 3,600 rooms in printed text, and by means of 200,000 photographs, in order to enable the judges to determine who was responsible for paying for the repair of which damages. This would have been impossible using traditional courtadmissible tools. So Austrian courts now accept this digital documentation tool-kit, and with good reason.

The following sections will attempt to assess whether this tool kit is able to meet the specific requirements for Kosovo's heritage inventory. The extensive teaching experience of the main author of this article has led her to that region of the Western Balkans before Kosovo declared itself an independent state in 2008. Since then, the author, together with the two other authors, her teaching assistants in Kosovo, and students of architecture at University of Business and technology (UBT), has endeavoured to contribute to the heritage inventory issues of the young state through intensively collecting material on its architectural heritage. This experiment unearthed the weaknesses of the existing heritage inventory systems: for example, what to do with documents or oral building histories if you do not want to transcribe them immediately into typed texts. Another unresolved question is the relationship the between numerous photographs of the sitesituation and the related plan document. Docu-tool ${ }^{\circledR}$ would seem to be the answer to both these questions, providing both an adequate tool-kit and platform. The following paragraphs will describe the assumed basics and the workflow for adapting the program to make it an efficient and reliable documentation tool in the field of architectural heritage inventory.

\section{CULTURAL HERITAGE OF KOSOVO}

\subsection{Cultural Heritage - Overview}

Kosovo has an extensive rich archaeological and architectural heritage that dates back to the Dardanian kingdom predating the Roman and Late-Roman administration and lasting until the $7^{\text {th }}$ century. Emperor Justinian, born in the region, left significant traces of ancient urban planning, but even before, early Christians left the territories noteworthy sacral building complexes. After a short interregnum, several Byzantine-Bulgarian-Greek-Orthodox Empires, including the kingdom of Raš, built up remarkable architecture, a blend between Western and Eastern cultural influences, recently declared UNESCO world heritage sites by state nominations of Serbia, hence based on the current territory of Kosovo. After this important era, the Ottoman emperors who governed the territories for nearly five hundred years brought not only Eastern comfort and luxury into the traditional residential house, which changed the local traditional tower-houses (s. kulla, pl. kullat) significantly, but also influenced the administrative and commercial centres through their distinct public architecture. After the collapse of the Ottoman Empire during the First World War, Kosovo and its neighbouring territories shifted into an advanced modernism, which reached its peak in the socialist planning strategies for urban apartment blocks of the 1960s, 1970s and 1980s. Then the former Yugoslavian Federation was split up by cruel wars. In 2000, war and different sanctions heavily affected the former autonomous province of Kosovo. After 2004, the situation calmed down under an international UN-EU administration. Although Kosovo declared independence in 2008, the state institutions have not yet recovered, for a number of reasons.

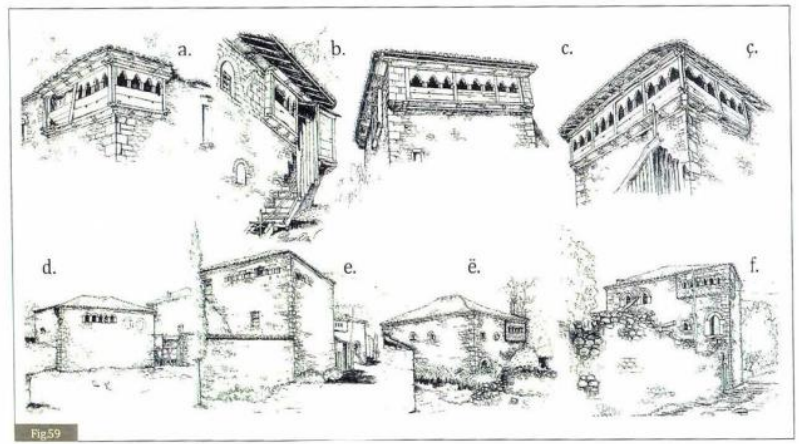

Figure 1. Typical traditional tower-houses of Kosovo (kulla) in drawings by the architectural historian Flamur Doli (Source: 2009, Arkitektura Vernakulare Kosoves, p. 193)

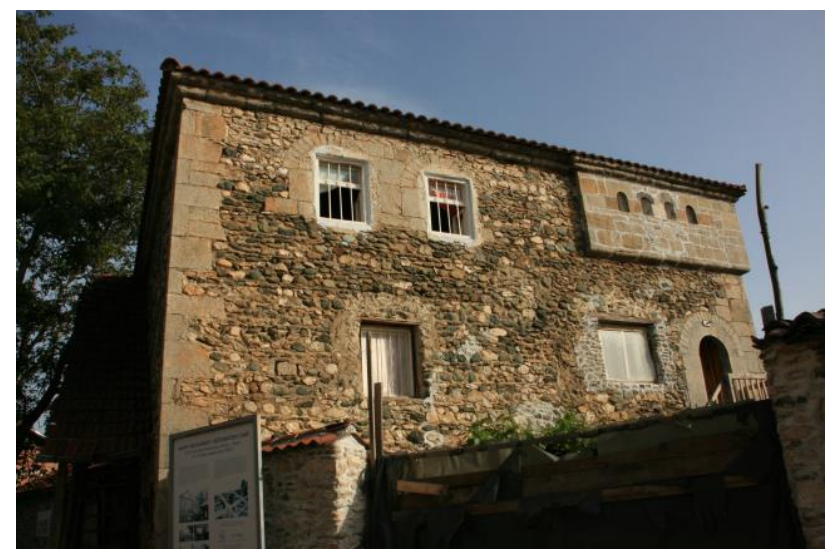

Figure 2. Typical traditional tower-house (kulla) in Dranoç, Western Kosovo (Photo: Jaeger-Klein, May 2015)

\subsection{Current Heritage Administration}

For Kosovo's architectural heritage, the several vast shifts in administration -from the Ottomans ruling from Istanbul to the Socialist Republic of Yugoslavia ruling from Belgrade and recently to self-administration via Prishtina for the first time in history - are a kind of ongoing disaster. Neither Istanbul nor Belgrade handed over its thorough and advanced knowledge on 
the heritage of the territories to the succeeding state. The legacy of 2000 and 2004 is that cultural politics is still marked by nationalistic announcements on the Kosovar as well as Serbian side. Additionally, for various reasons, Kosovo currently does not have settled state institutions, which can protect and maintain its architectural heritage; the legal basis is still unclear and there is no reliable, comprehensive inventory. Hence, a lot of material is there, but scattered and still mostly inaccessible to the public, mostly in private (family knowledge) and semi-private (universities, NGOs) archive-pools. Furthermore, the various holders of the material do not want to cooperate or share their knowledge.

\subsection{Cultural Heritage Institutions}

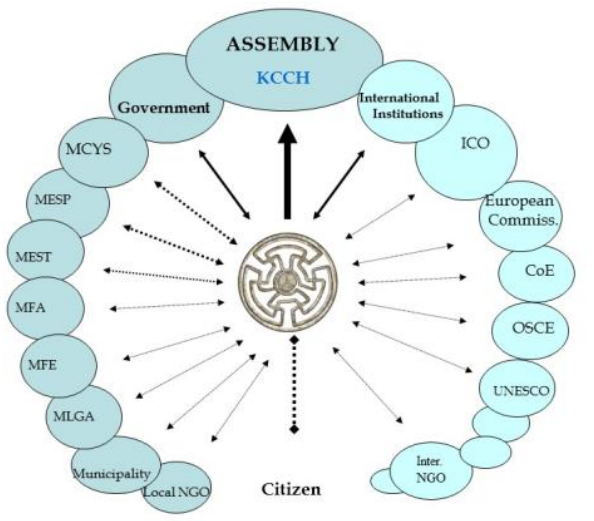

8

Figure 3. The situation of the Kosovo Council for Cultural Heritage $\mathrm{KCCH}$ expressed in an emotional organigram (Source: Edi Shukriu, 2013, ICOMOS South-East European Regional Conference)

Who are the various parties in Kosovo involved in the architectural heritage agenda? On the state side, there are at least three different ministries. The Ministry of Culture, Youth and Sports (MCYS) as well as the Ministry of Environment and Spatial Planning (MESP) act as government authorities within their specific fields. Nevertheless, because of the national (chauvinistic) aspects of cultural heritage between ethnic Serbs and ethnic Kosovo-Albanians, the issue is also on the agenda of the Ministry of Foreign Affairs, which since 2015 has been trying to push Kosovo's UNESCO membership - another agenda closely related to cultural heritage. At the institutional level, there are again far too many agents for such a small country. In addition to a kind of National Institute of Monument Protection (IMMK) and a Kosovo Archaeological Institute, there are Regional Centres for Cultural Heritage ( $\mathrm{RCCH})$ and the municipalities. The Kosovo Council of Cultural Heritage $(\mathrm{KCCH})$ coordinates the governments' and the institutions' efforts in a kind of general assembly format, but the Kosovo Academy of Sciences and Arts also acts as a national control mechanism. In addition, various UN- and EU-financed tracks also deal with cultural heritage issues, but always seemingly the single actions of a rapidlychanging succession of individuals, without a coordinated evaluation and dissemination of the results. The university scene of Kosovo is very similar: in addition to the public University of Prishtina (UP) several private, accredited universities fill the big gaps in the country's higher educational system. Several of these have a department of architecture and history of art and work in the fields of cultural heritage. Nobody is coordinating these efforts either, although this would logically be the responsibility of the Kosovo Council of Cultural Heritage.

\subsection{Cultural Heritage Lists and Inventories}

An inventory of its cultural heritage assets is essential for the country. This is of urgent importance in both contexts, to complete its legal framework and for joining UNESCO. However, the state institutions seem not yet to have understood, that an inventory involves far more than just a list of national monuments. Even the lists compiled and published are often inaccurate: even basic information such as ownership status, address and even the location is frequently missing.

In an attempt to redress the situation, in December 2012 the EUfinanced study "Conservation Basis for the Historic Centre of Prishtina - A Case Study on Integrated Conservation", was published. The study serves as role model for an adequate "firstaid' inventory basis meeting international standards. Under the leadership of Julija Trichkovska, Senior Specialist on Cultural Heritage of the PCDK (Promotion of Cultural Diversity in Kosovo - EU/CoE joint project) two qualified architects, Avni Manaj (PCDK) and Valbona Saliuka (RCCH - Regional Center for Cultural Heritage) Prishtina, developed a system for making a quick inventory. Together with several colleagues and students of architecture, they used the system to document the few remaining historic buildings of Prishtina. The result consists in a double column, multi-line matrix with text blocs as a basis for further actions.

\begin{tabular}{|c|c|}
\hline No. 18 & \\
\hline Name of the cultural heritage asset & House of Mr. Kurtesh Sylejmani \\
\hline Address & $\begin{array}{l}\text { "Sutjeska", St. No.11 (old) / "Mehment Kaçurri", St. } \\
\text { (new) }\end{array}$ \\
\hline Old cadastral parcel & 13260 \\
\hline New cadastral parcel & 4959-0 \\
\hline Cartographic reference & $X=7,513,589.08, Y=4,725,199.7,600 \mathrm{~m}$ \\
\hline Original function & Residential \\
\hline Current function & Residential \\
\hline Date & 1880 \\
\hline Type of ownership & Private \\
\hline Materials & $\begin{array}{l}\text { Blend of wood plank; mud, clay brick, lime mortar, } \\
\text { "Turkish" roof tiles }\end{array}$ \\
\hline Condition & Poor \\
\hline $\begin{array}{l}\text { Factors influenced to the integrity } \\
\text { of the heritage / vulnerability }\end{array}$ & $\begin{array}{l}\text { Lack of maintenance, lack of conservation/resto- } \\
\text { ration interventions }\end{array}$ \\
\hline Type of protection / legal status & $\begin{array}{l}\text { Listed before } 2000 \\
\text { There is no information on decision for its current } \\
\text { legal protection status. }\end{array}$ \\
\hline Statement of significance & $\begin{array}{l}\text { Very rare example of residential buildings of its } \\
\text { type in the area. The construction is a blend of } \\
\text { wood plank and construction technique named } \\
\text { "bondruk", which is very typical for the Balkan } \\
\text { vernacular architecture. The upper floor is with } \\
\text { prominent "erker"(an oriel) which is formed to ap- } \\
\text { pear as a cantilever over the wall. It is constructed } \\
\text { to support the raised sitting area within the room. }\end{array}$ \\
\hline $\begin{array}{l}\text { Protection regime/ } \\
\text { Recommendations }\end{array}$ & $\begin{array}{l}\text { Immediate action for conservation/restoration } \\
\text { interventions on the building structure using the } \\
\text { original materials; appropriate maintenence. }\end{array}$ \\
\hline Compilers & $\begin{array}{l}\text { Besë Morina, Dardane Uka, Valmira Osmani, stu- } \\
\text { dents of architecture }\end{array}$ \\
\hline Controller & Valbona Saliuka, arch., RCCH- Prishtinë/Priština \\
\hline Date & May-June 2012 \\
\hline
\end{tabular}

Figure 4. Model inventory according to international standards as basis for integrated conservation actions (Source:

Conservation Basis for the Historic Centre of Prishtina, p. 54)

Each object is numbered and linked to the plan documents giving the location, age, condition and the ownership status of the buildings. The categories are the following: address (in the case of Kosovo old and new street name) and usual name of the asset; ownership (name and type); cadastral parcel number (old and new); cartographic reference; original and current function; approximate or exact erection date; materials, condition; factors 
influencing the integrity of the building; type of protection and legal status (in the case of Kosovo, former and current); statement of significance; protection regime and recommendations; names of the data collectors. However, such an inventory, even with its inevitable mistakes, needs a certain knowledge base and also discipline and order, to be successful. Neither of these is available in Kosovo to a sufficient extent to complete the country's inventory to a satisfactory international standard. To locate the whole stock of monuments in Kosovo requires a focus on completeness, a new approach and effective self-explanatory tools, especially since so much time has already been lost.

Furthermore, 'classical' inventory handbooks like the Austrian Topography of Art series or the German Dehio handbooks list and sort the collected information on the assets according to postal address. However, countries in transition, such as Kosovo, prove that this is approach has only limited success if an existing postal system changes or is dismantled, as happened in Kosovo after its war for independence in 2000. It took until 2014 to reinstate the postal system, which had completely new names and cadastral parcel numbers - and people are of course not very familiar with the new system. Therefore, the only efficient topographical description system is now a GIS database such as Arches, a Digital Heritage Inventory and Management System. The issue that remains is to find a documentation tool to collect and prepare the data efficiently and adequately for the subsequent processing within the Arches and/or other systems. However, whereas the collection of the material will be done by laypeople rather than specialists, working with the Arches program requires some knowledge and experience in the field. This is similar to the legal building issues in Austria, where judges and lawyers who are untrained in plan reading had to interpret relevant documentation material consisting of technical plan drawings, sketches, photographs from the site and the audio data collected by expert witnesses and their auxiliary staff to support the decisions of the court.

\section{DOCU-TOOLS $®$ AND ITS ADAPTATION FOR CULTURAL HERITAGE ISSUES}

\subsection{Docu-tools $®$ for building documentation}

Reliable and immediately on-site documentation has become a key part of successful building documentation, both during the building process for subsequent facility management. An inspector has to gather together photos, written notes, audio and video files, and oral contracts on-site as well as sketches and plan graphics from the various planning offices. A dependable system translates the information into accurate reports for every member of the building team, from the building owner to the planners, from the contractors to the contractor's partners. The information has to be reliable, immediately accessible by every team member, easy to handle, affordable and finally provable - admissible even in court.

Docu-tools $®$ starts with a pin on the digital plan graphics or photographed sketch on the smart phone, tablet computer or laptop on-site or in the office. Each pin in the plan document is linked with photographs, verbal comments, sketched details, text documents, videos, etc., and with its unchangeable timestamp. The combination between unchangeable timestamp and location enables a secure and provable identification of the Who, What, When and How of the documented feature. The users can only feed in information, but not change or delete it. The workflow is archived forever.

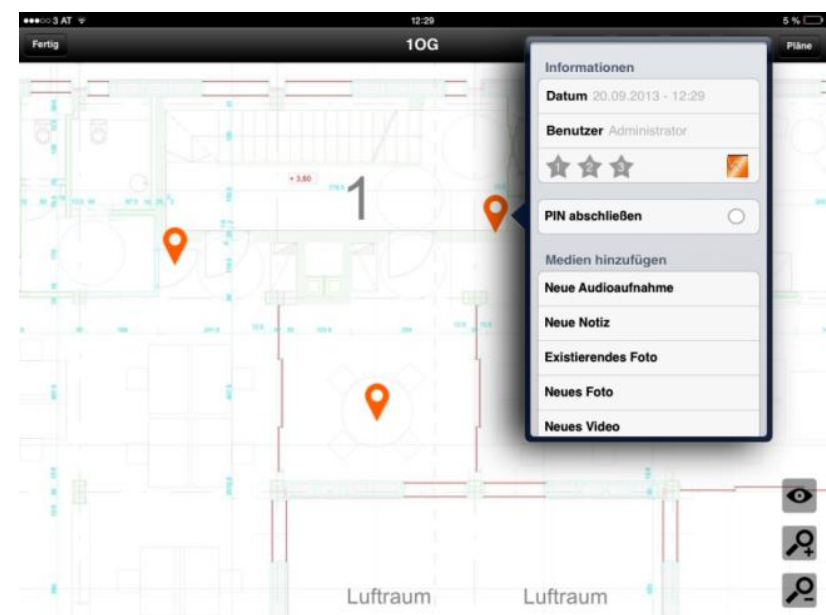

Figure 5. Docu-tools ${ }^{\circledR}$ pins within the digital plan document of a new construction site and list of the media attached to the pin

Docu-tool ${ }^{\circledR}$ 's best feature is its simple handling of the photographs and associated information and their location in reality via plan graphics or sketch. You mark a location by putting a pin in the plan document and make a photograph of the same situation. The program knows exactly what building the photograph belongs to, the author and when it was taken. Of course, external professional photographs can also be clearly located within the graphical document.

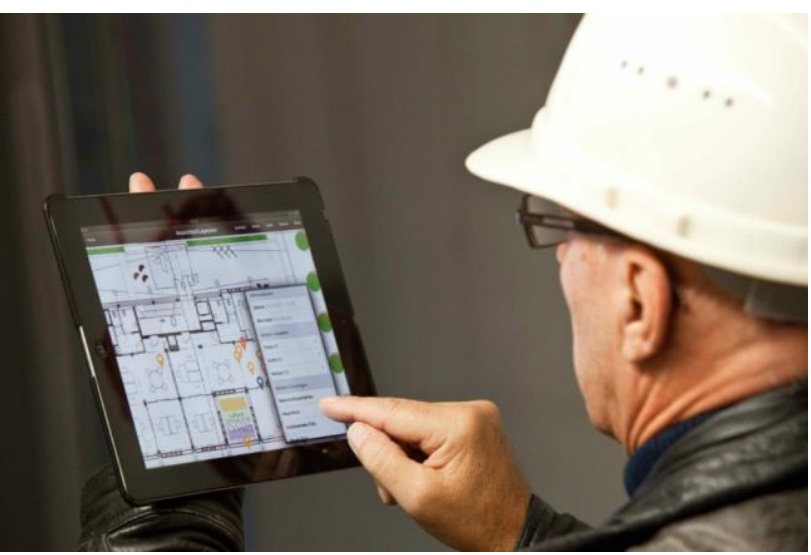

Figure 6. Docu-tools ${ }^{\circledR}$ feed-in on-site via tablet computer

Additionally, one can make an oral or written comment on the location and associated photographs. If desired, the tablet computer's automatic language identification program will transform the oral comments into written documents automatically. The user can even have separate internal comments for selected partners and official, external ones, readable by all. Immediately or later, the pin can also attach additional documents and further information and link them to the plan and photographs.

The basis for the pin consists of digital CAD-files in all current formats, dwg, dxf and jpg, but also scanned sketches and historic plans, even pictures. This feature in particular makes for a portable office, as all the documented material is always to hand, enabling users to verify congruency with the actual situation. Additionally, various selection criteria flag up essential items of the building documentation such as damages, date of completion and expected additional costs on-site. Of course, it also permits pictures, their location and all other information to be sent immediately from the site to other project partners in their 
offices. The main advantages of the new tool are its efficiency, reliability and ease of handling, but also the possibility to work with a combination of different data formats, unlike the usual heritage inventory programs, which are in principle in database format.

\subsection{Classical inventory books}

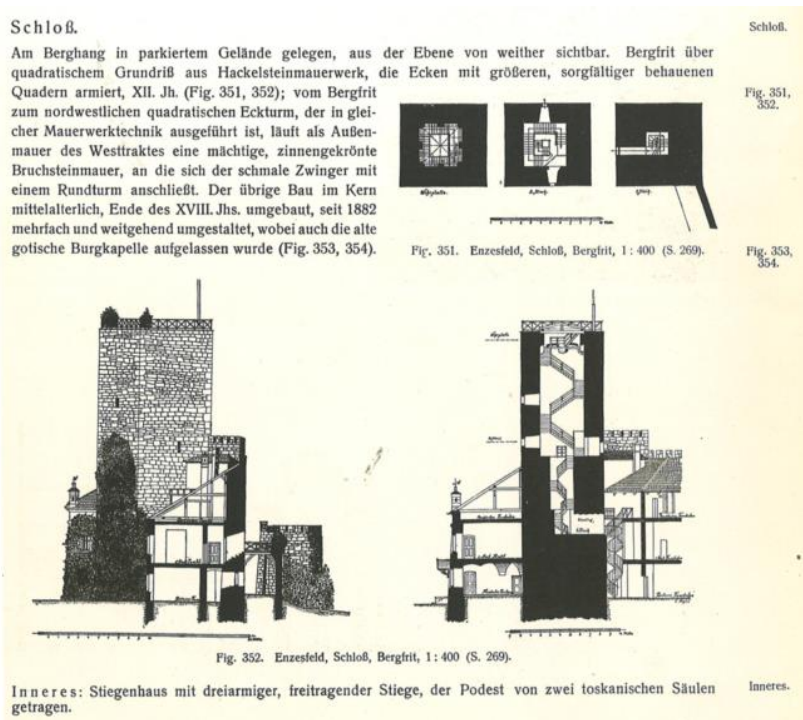

Figure 7. Example from an Austrian Art Topography Volume from the year 1924: Combination of descriptive text and technical drawings in scale

Even the first published inventories, based on object lists with postal address, erection period and name(s) of the planner(s) as well as author, were more than lists or pure descriptive texts. From the very beginning, their attraction and usability lay in the combination of facts, descriptive texts, plan graphics, perspective and axonometric drawings of buildings and objects, watercolour pictures, photographs and maps. Already early inventory advices like a document for Bavaria from the year 1904 underline that as many illustrations as possible should be given additionally to the floor plans, sections and elevations of single objects and that the object has to be embedded into its surroundings (Compare Huse, 2006, 170-171).

As already mentioned, the different locations were sorted according to geographic and administrative criteria. The provinces and districts gave the major structure, the usual site names provided the second level of description and for bigger units such as those within villages, towns and cities, and the single assets were afterwards sorted alphabetically by postal address (street name and object number as registered administratively). This works well, as long as there is a postal system in place, as I have explained before, which is the case for the birthplace of inventories in central Europe, but for a global inventory system we soon find that system to be inadequate.

Another, related characteristic of inventories are selection options in form of registers. They allow a quick finding of the objects by certain selection criteria. For example, the indexes of the classical inventory books list not only the locations in alphabetical order, but also according to artists and architects, important craftsmen or sponsors of the assets, or other special features such as building type (churches, monasteries, palaces, castles, administrative buildings, schools, hospitals, etc.). Conventional register systems urgently need more flexible methods of selection than analogue media can provide.

Frain $204 \quad$ NIEDERDONAU

auf dem Gipfel des Felsens gelegenen ma. Hauptburg lagert das 1686 bez. hufeisenförmige dreigeschossige Schloß. Der ö. Querflügel wurde als Vorbau zum Ahnensaal $171 \mathrm{I}-20$ umgestaltet; Doppelfreitreppe mit 2 für das Tor der Reichskanzlei in Wien bestimmten Riesengruppen Herkules und Antäus, Aneas und Anchises von Lorenzo Matielli. Auf den großen querelliptischen kuppelgwbt. Vorsaal mit späteren klassizistischen Grisaillemalereien (Puttenfries) folgt der elliptische, $26 \mathrm{~m}$ lange und $15 \mathrm{~m}$ hohe * Ahnensaal, 1690 (1685 ?)-94 von Johann Bernh. Fischer v. Erlach an Stelle der got. Burg-Kap. erb. Der kuppelförmig gwbt. Saal ist von mächtiger Raumwirkung. In den von Pilastern
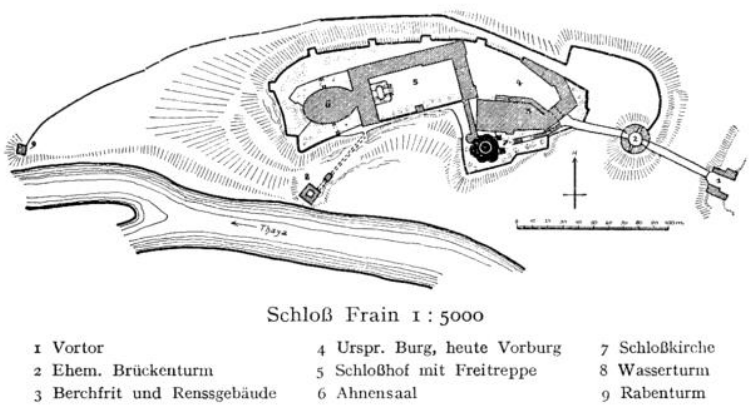

Figure 8. Example of the Dehio Handbook from 1941: Combination between descriptive text and site-plan with index of the parts of the ensemble and visualization of the topography

\subsection{Digital inventories}

Many of the shortcomings described above can be remedied by having digital inventories. Cartographic references in pictures using a pin on the map or an air view of the region is the obvious replacement for the alphabetical postal address system, and we have already used to such contemporary methods due to the widespread use of smartphones and smart tablet computers, which have the enormous advantage of being fully portable. This means that the genuine document is produced on-site and unfiltered, using a combination of photographs of the in-situ condition and audio-documents by the author. Additionally it enables the author to interview on-site or elsewhere anonymously if desired - any illiterate owners of a site, contemporary witnesses of damage, passers-by regarding their even faint knowledge of a monument and so forth. As far as we know, existing digital inventories have not incorporated many of these options for recording and documenting architecture. Of course, the information collected is completely unfiltered, but unlike classical inventory books, it can be commented on, discussed, modified and revised quite easily.

The price for this new flexibility and ease of use is that the reliability of the information collected then needs to be verified, as for all digital information in general. The printed books underwent several stages of approval to ensure that information was reliable. The new generation of digital inventories created through open-society processes will have to go through the same process as Wikipedia. First, everything has to be accepted as possibly useful information, but not approved. Information will be corrected and completed by other users who have updated knowledge. This is why it is so important that all information stored in programs such as docu-tools ${ }^{\circledR}$ is undeletable: so that the genesis of the knowledge can be approved by everybody at any time. 


\section{WORKFLOW FOR ARCHITECTURAL HERITAGE INVENTORY IN KOSOVO}

The following steps briefly outline the suggested workflow for an efficient and thorough pre-inventory of the architectural heritage of Kosovo with the assistance of architectural students from all the universities in the country, as part of their academic training. In 2014, UBT Prishtina launched a campaign for students of architecture to collect architectural heritage information under the supervision of the co-authors of this paper. This experiment showed that the task has to be approached with other means than the classical heritage inventories. Most of the information obtained did not come from literature research, but from the families of the owners themselves. So, as Step 1, we now suggest the collection of oral information on cultural heritage using docu-tools $®$. In Step 2, the collected information has to be identified within the topography of Kosovo and merged with the available published information. At this stage, the document structure of docu-tools ${ }^{\circledR}$ should be configured to the international standards for archaeological and architectural heritage, so as to be compatible with Arches and other digital inventory programs for cultural heritage.

Next, governmental structures such as the Ministry of Culture, Youth and Sports (MCYS) would send out a Kosovo-wide call to the universities, institutions, NGOs and private individuals, who have collected and archived material so far, to cooperate in handing-over their collections. This would certainly be beneficial to the country's general effort to become a member of UNESCO - Step 3. A team of collectors, trained in the specific programs, best of state paid local volunteers for a limited time, and recruited from the universities, could sort and classify the collected material in Step 4. It is thought that steps 1 to $\mathbf{4}$ will lead to a reasonably useful pre-inventory for Kosovo, which can then be used as a starting point for a further, more comprehensive inventory.

Step 5, an EU-financed ErasmusPlus Strategic Partnership training would enable students from partner universities to make a systematic search and collection of missing material throughout Kosovo and collect the data on-site using docu-tools ${ }^{\circledR}$. The staff of state institutions in Kosovo could also be trained in the use of docu-tools ${ }^{\circledR}$ as Step 6, whereby the users hand over the collected material to state institutions, but retain the original stock of collected material in an open-source platform such as Arches, accessible to civil society. Under the final step, Step 7, the state institutions can add their specific, non-public information. A particular configuration of docu-tools ${ }^{\circledR}$ would permit the information to be separated into public and not-publiclyaccessible heritage information. In parallel, education on heritage inventory methods using docu-tools ${ }^{\circledR}$ and other database inventory programs to international standards will be embedded in the academic curricula of all ErasmusPlus Strategic Partners.

\section{CONCLUSIONS}

Countries in transition, such as Kosovo in the Western Balkan often cannot establish architectural heritage inventories, due to a lack of specially trained staff within their institutions. Hence, civil society has collected useful material on the heritage of the region. An easy-to-use, effective tool for documentation and a transparent, open-source heritage platform such as Arches from the Getty Trust and World heritage Monuments Fund would enable an 'open society' inventory to replace the incomplete state inventory. The Austrian docu-tools $\AA$, program, which was configured for building documentation, can be adapted for heritage documentation, to support international digital heritage inventory and management programs, particularly in those regions where the heritage documentation and inventory has to be (re)started from scratch. A coordinated educational and training program such the EU ErasmusPlus Strategic Partnership could be used to build up, in a seven-step format, the cultural heritage inventory of such regions within a reasonably short time frame. Kosovo and other countries in transition urgently need such digital tools and workflows in order to build up their states and to be able to join international organisations such as UNESCO.

\section{REFERENCES}

Doli, Flamur, 2009. Arkitektura Vernakulare Kosoves, Prishtina.

Frey, Dagobert, 1924. Die Denkmale des politischen Bezirkes Baden, Band XXVIII der Österreichischen Kunsttopographie, Wien.

Berisha, Milot, 2012. Archaeological Guide of Kosovo. Prishtina.

P. K. Carlisle, I. Avramides, A. Dalgity, D. Myers, 2014. The Arches Heritage Inventory and Management System: a standards-based approach to the management of cultural heritage information. (c) English Heritage, World Monuments Funds and the J. Paul Getty Trust.

Ginhart, Karl, 1921. Dehio Handbuch der deutschen Kunstdenkmäler in der Ostmark. Erster Band. Wien und Niederdonau, Wien-Berlin.

Huse, Norbert (ed.), 2006. Grundsätze für die Inventarisation der Kunstdenkmäler Bayerns, 1904. In Denkmalpflege. Deutsche Texte aus drei Jahrhunderten, 167-179. München.

Kosova Academy of Sciences and Arts (ed.), 2013. Kosova. A Monographic Survey. Prishtina.

Krasniqi, Artan, 2014-2015. Monument, Vëllimi I-III, Prishtina

Lehne, Andreas, 2008. Georg Dehio, Alois Riegl, Max Dvořák a threshold in theory development, In Conservation and Preservation. Interactions between Theory and Practice. In memoriam Alois Riegl (1858-1905), 69-80. Proceedings of the International Conference of the ICOMOS International Scientific Committee for the Theory and Philosophy of Conservation and Restoration. 23-27 April 2008, Vienna.

Malcolm, Noel, 1998: Kosovo. A Short History. New York.

Rant, Matthias, Schuster, Gerhard, 2013, Docu-tools ${ }^{\circledR}$ im Werkstattgespräch, IBO magazin 4/13, 27-29. 